\author{
Mariantonia PALACIOS
}

Central University of Venezuela

\title{
MUSIC IN 19TH-CENTURY VENEZUELA
}

ABSTRACT Beginning as a Spanish colony to become an independent republic - the 19th century was a pivotal point for Venezuela. Socially, politically, and economically speaking, the changes were numerous, and so were the cultural and artistic manifestations that flourished in those circumstances. One of them will be tackled in this study: music. This paper is a review of one of the richest information sources: the publications of the times. Venezuelan 19th century hemerography contains hundreds of music news on composers and their environment, works, performers, musical institutions, events, concerts, critical reviews, and others of the sort. They are the witness of the events of an epoch. By analyzing them, a partial reconstruction of the Venezuelan music history can be made possible.

KEY WORDS Music, 19th century, hemerography.

\section{INTRODUCTION}

Venezuela enters the 19th century as a colony of the Spanish Empire. Three centuries have passed since Columbus and his cronies arrived to conquer and colonize these lands on behalf of both the Spanish Kings and the Pope. Three hundred years later, people on this side of the Mar Oceano decided to forge their own independent destiny. Financial, political, and social unrest had inflamed feelings among white criollos (those born in Venezuela). The turning point of the events that ended up with the Independence declaration was the overthrow of Ferdinand VII of Bourbon by Napoleonic armies. On July 5th, 1811 the act was signed that sealed Venezuela's 
destiny as an independent state. Years of fierce fight against Royalist troops consolidated its aspiration. Finally, after a period of political maturation and intestine wars, the 1830 central federal Constitution gave shape to a sovereign country, detached from the Great Colombia. Little by little, and not without resistance, Venezuela left behind its former colonial order. These were the times of autocratic caudillos, a lineage that began with General Jose Antonio Paez (1790-1873) and ends with General Juan Vicente Gomez (1857-1935).

The caudillo is the new representative; an unchallenged power, human synthesis of the material power - physical, financial, social - halo-crowned, with the magic of "prestige" and its ineffable charismatic projection. Authoritarian, basic and high-handed, of mixed positive and negative qualities, he can make wonders in the social life. ${ }^{1}$

Of the succession of caudillos that were in the power in the newly-born republic, what is of our greatest interest, for this article, the period of Antonio Guzman Blanco (1829-1899), "El Ilustre Americano." Not only because he was the character that stayed in power longest (a three-time President: 1870-1877, 1879-1884, and 1886-1887), but also because of the boost and the importance in the growth of arts, especially music and painting, and for his efforts to drive the country to modernity.

Venezuela lived important advances during the Guzman Blanco autocracy. He was the only among the Venezuela tyrants that, before arriving to power, had been to Europe, and had lived in the US, and the only one with a university degree. He had the capability and modern ideas to carry out a civilizing work: he decreed free and mandatory primary education, possibly his greatest feat... Under his administration, boulevards, theaters, churches, aqueducts, railroads, streetcars, and street lighting were built, and many and important initiatives were materialized. ${ }^{2}$

Many were the factors boosting art development during the Guzman Blanco administration. Besides financing to events, spectacles and groups, the Instituto de Bellas Artes (Fine Arts Institute) was founded in 1870, scholarships were granted to outstanding artists to fund their training abroad from 1873 on, and in 1881 the Guzman Blanco theater was opened - the epicenter of the cultural life of the city of Caracas. During those years a great number of periodicals related directly or indirectly to music and music industry flourished. ${ }^{3}$ Being either general periodicals with music-related news or cultural ones with sections dedicated to music, or, finally, ones exclusively dedicated to musical topics, this hemerography is the core source for the study of the development of music in the Venezuela of the mid-19 century.

J.L. Salcedo-Bastardo, Historia Fundamental de Venezuela, Caracas 1993, s. 328.

2 Ibid., s. 369.

A listing of Venezuelan periodicals related to 19th century music can be found in M.G. Lisbona, 'Salvador Narciso Llamozas, Lira Venezolana y Nacionalismo musical', Revista Musical de Venezuela, № 41 (2000), p. 210, and F.L. Rodríguez Legendre, Caracas, la vida musical y sus sonidos (1830-1888), Caracas 1999, pp. 190-212. 


\section{MUSIC IN 19TH-CENTURY VENEZUELA}

A survey of documentary sources and specialized literature can give us an idea of the music that was composed, listened to, played, and danced to during this period.

In order to fully understand musical preferences of the epoch, it is necessary to mention a characteristic aspect ofthat historical moment: the second half of the 19th century, particularly the Guzman Blanco-ruled age. It was a time of Francophilia - as far as tastes and customs were concerned. Guzman had for many years lived in Paris, and always showed his admiration for French culture, and particularly for the beauty and the order of the city. During his administration, Guzman set out many urban reforms for Caracas to look like the City of Light: he built buildings, roads, parks, and big avenues, installed the lighting system, refurbished façades and gardens. Cultural elites in Venezuela adopted the manners, attire, and culinary tastes that matched the urban reforms by the "Ilustre Americano". ${ }^{4}$ American journalist William Eleroy Curtis, special commissioner of the US government for Central America and South American Republics, described the cities thus: ${ }^{5}$

Caracas is a sort of one-story Paris. The shops are all Parisian, and sample bonnets and costumes are coming over by every steamer. All the dress-makers are French, and most of the shops at which wearing-apparel is sold are kept by Frenchmen, who, of course, buy their goods at home. It is no uncommon thing to find every lady around the table at a dinner-party wearing an imported costume, and when they go out to drive those who can afford it aspire to wear a Paris bonnet, like their sisters.

\section{LYRIC THEATER}

Attending theater was part of the new status-giving social ritual. The public arrived in throngs to attend opera and zarzuela recreation, two genres that caused furor in Venezuela and the rest of Ibero-America. It was the perfect time to watch and be seen. Periodicals were in charge of reminding attendees about the code of conduct, the courtesy rules, and good manners expected of a respectable audience. Additionally, they would also comment on the content of the works in order to prepare the audience for what they were about to see. Everything was aimed to "educate".

Many were the opera seasons held at Teatro Guzman Blanco, the most important and modern in Caracas, albeit since 1836, there were news of performances at Teatro del Coliseo, at Teatro Union (or Zarzuela Theater), at Salon de Apolo, and

Almandoz M.A., 'Postales de viajeros olvidados a la Caracas de entre siglos' in J.J. Martín Frenchilla, Y. Texera (comps.), Asi nos vieron. Cultura, ciencia y tecnología en Venezuela 1830-1940, Caracas 2000, pp. 31-76.

5 W.E. Curtis, Venezuela. A land where it's always summer, New York 1896, p. 153. 
at Teatro de Caracas. ${ }^{6}$ The most important among those was the opera Virginia by Venezuelan composer Jose Angel Montero (1832-1881), first presented on stage at Teatro Caracas in 1873.

Although Italian opera reigned in theaters, zarzuela was of special interest because the texts were in Spanish, melodies were easier to memorize and, they mixed music with speech, dance, and choirs. We have news of zarzuela companies visiting the country from as early as 1859 , when a lyrical-dramatic Spanish group lead by Mrs. Zafrané presented the zarzuela in one act, El amor y el almuerzo. Approximately at this time, composer Jose Ángel Montero wrote his first zarzuelas El Cumpleaños de Leonor y Los alemanes en Italia.

\section{PHILHARMONIC SOCIETIES AND MILITARY BANDS}

Both operas and zarzuelas were often presented by foreign companies touring many cities of Venezuela. They would hire local players ad hoc for the forming of the orchestra and choirs. At times, they would have the assistance of a national director. But not always would they obtain the best results, either because of the lack of available players or because of the lack of appropriate payment. Most eloquent and humorous was the comment by chronicler of the musical El Zancudo in this regard. In his texts he encourages visitor opera companies to prize somehow those who have gotten them out of more than one trouble. We are talking about first violins, violoncello and the double bass, who have supplied with their quality the number to make a whole orchestra, a number that needed to be "integer", and which unfortunately turned out to be a "fraction", as never was the concert "unit" achieved.

These orchestra groups hired by piecework were not the only ones working at that time. In the 19th century emerged many of the so-called philharmonic societies or units, orchestra groups made up of teachers and talented students that would hold concerts on a regular basis. Most of them were civil organizations supported by their creditor with a double purpose: offering concert seasons and taking care of the musical education of their members. In 1811, first references to these credit concerts are found by musician Landaeta in the newspaper El Mercurio Venezolano: ${ }^{8}$

Prospectus for the Subscription to a Vocal and Instrumental Musical Contest.

1. Subscription shall be 6-month long, with 4 concerts each that shall span from 8 to 11 p.m.

2. Orchestras shall be made up of 25 musicians, the most talented in the City.

3. Mandatory Concerts of all the instruments shall be held in the season.

6 For more details on the opera and zarzuela seasons in Caracas prior to 1881, see F.L. Rodríguez Legendre, Caracas, la vida musical..., p. 88.

7 El Zancudo, Año 5, Mes 4, № 10, 25 April 1880.

8 El Mercurio Venezolano, № 2, Febraury 1811, p. 54. 
4. Ladies and Gentlemen who would like to subscribe shall do it by giving 25 Pesos each for the whole 6 Months, whose amount shall be showcased in advance in order to defray necessary expenditure.

In the following year, there is reference to the first pay balls, balls that could be attended to through the payment of a ticket. These events, which were previously only of aristocratic-exclusive access, were now accessible to any person with enough resources to buy the ticket, showing thus a democratization of the musical habits in Venezuelan society.

Philharmonic societies or unions coexisted with other type of orchestra groups: bands. These, once the Independence War was over, continued working, but more civilian-oriented. They held concerts in public places known as retretas for the enjoyment of citizens. The repertoire they would play was made up of Venezuelan "national and patriotic" airs, along the arrangements that were the hit in other countries. Opera and zarzuela fragments specially arranged for this type of groups were also part thereof. Players as famous as Federico Villena (1835-1899), Leopoldo Sucre (1838-1902), Albino Abbiati (1814-1890), Ramon Montero (1839-1881) y Pedro Elias Gutierrez (1903-1946) were in the head of these ensembles, and obtained much popularity with them.

\section{THE PRIVACY OF THE SALON}

Not all the mid-19th century music was intended to be played in public places or by a middle-size group. Many were composed to be played, listened to or danced to at home. It is the so-called "salon music"(musique de salon, French term related to social meetings). These spaces, good for the reinforcement of social and family links, were the meeting points for the discussion of political, literary, and arts topics.

The played repertoire in these 18 th century gatherings, meetings or soirées was made up mainly of dance pieces such as waltz, mazurkas, dances, counter-dances, minuets or bambucos; or small-sized European-style works such as fantasías, caprichos, barcarolas, romanzas, impromptus, nocturnes, marches, etc.

As for the dancing genres, Venezuelans' favorites in the second half of the $19^{\text {th }}$ century were waltz and dances - they acquired local characteristics that differentiated them from the European versions, especially in the rhythm. Salvador Narciso Llamozas (1854-1940), one of the most outstanding composers, pianists, critics, editors, and instructors of that time, describes el valse aclimatado in La Lira Venezolana, a magazine edited by himself:

Listen to Venezuelan waltz and there will come to your mind memoirs of the tropical nights, with their splendid and gorgeous moons, the serenity of its blue, limpid sky, the melancholy of the aboriginal hymns, and all that magic within the moving poetry of the native home.

S.N. Llamozas, 'El valse venezolano', La Lira Venezolana. Revista quincenal de Música y literatura, No 14 (1883), p. 65. 
(...)

Even in the way of dancing such airs there is a charming I-don't-know-what, which differs much in the galloping movement of foreign waltz, and to their sound is that Venezuelan ladies show their unique poise, a reflect of the Andalusian grace, so seducing and captivating, as the intoxicating essences of the American flora.

\section{(...)}

In comparison to the structure of our waltz, it is the same as in the European waltz, but how much difference in rhythms and movements! what an originality of cuts and cadences! what clever and lively accompaniments! The first part, originally writing in the minor mode, is melancholic and paused; melody waves smoothly, full of a voluptuous abandonment, as the palm swaying in the fields to the drift of the morning breeze. But, at the beginning of the second part, rhythm revives and inflames, and then sparkle the almond eyes of the dark-skinned woman moving her dancing waist in vertiginous spins, dashingly moving to the song of that fervent and sultry music... However, the physiognomy of Venezuelan waltz is not only the melodic character of its airs, but its variety of accompaniments, which bring despair to foreign instructors that have lived long with us.. When they listen to these offbeat rhythms their nerves would turn on because of such strange combinations, and they would feel powerless when trying to play it with the required movement.

As waltz, dance also endured transformations. Prussian doctor and musician Carl Sachs (1853-1878) was a witness of that. He settled down in the town of Calabozo (state of Guarico), in the Llanos, to study some fish species between 1876 and 1877. There he took part of the city's social life with invitations to parties and feasts. His observations and experiences were gathered in a post-mortem book; Aus den Llanos, Schilderung Einer Naturwissenschaftlichen Reise Nach Venezuela. Sachs attended to a dance he describes in detail in his book. Of dance, he highlights its rhythm in the second part - the set gains a most strange, halting sound the European ears can barely get used to initially. For Sachs, these strange rhythms are undoubtedly just natural to Venezuelans and are very strange to foreigners, up to the point of calling them "exasperating". ${ }^{10}$

As stated above, additional to the dancing genres, the repertoire played in salons included European pieces to "be listened to." These are romantic compositions mainly written for piano, where are explored the instrument's expressive and idiomatic resources. Nocturnes, caprichos, impromptus, scherzos were among the most learned genres. But undoubtedly, fantasias and variants on opera and zarzuela themes were of the largest preferences, as they allowed the player to show off more and a larger empathy with listener. There are also examples of this repertoire for violin and violoncello, although in a minor extent, as piano was the king of the instruments in the bourgeois salon.

10 Quoted in V. Benedittis, Presencia de la música en los relatos de viajeros del siglo XIX, Caracas 2002, p. 184. 


\section{THE REIGN OF THE PIANO}

Undoubtedly, the piano was the leading instrument in Ibero-America during the second half of the 19th century. There was no wealthy family without one, and no young lady without having the duty of learning how to play it. It was a symbol of status, prestige, and economic power. People would speak, dance, play and listen to music around the piano. This settled the basis for a lucrative business of selling, renting, fixing and maintaining of these instruments, and their fabrication in local workshops was also encouraged. Venezuelan Lorenzo Rodriguez Colina won a golden medal in the exposition held in 1883 in the Simon Bolivar's hundredth anniversary because of the good quality of his pianos, built with Venezuelan materials.

The piano became the unifying agent of the musical aspirations for both professionals and amateurs in the privacy of salons, as it was the favorite instrument in the concert rooms. This preference encouraged the arising of high-level concert pianists. In Venezuela mention must be made of an eminent pianist, Teresa Carreño (1853-1917), who shone internationally. Like her, many national performers had the possibility of doing their careers beyond our boundaries, although with not such a success. It was the case of Redescal Uzcategui (1871-1943), Ramon Delgado Palacios (1867-1902), and Narciso Salicrup (1869-1910).

Piano's popularity made of it the granted means of livelihood for many musicians, as there was a demand for apprentices, especially women. Many professionals made a living by providing private piano lessons to young ladies. They would teach to play the instrument's own repertoire and also to accompany the trending dancing genres. This accompaniment would be done four-handed - two pianists sitting at the same instrument. The one on the left of the keyboard would do the accompaniment rhythms and formulas for every type of dancing piece, while the one on the right would play the melody with some adornments. In Venezuela there were eminent masters in the art of the piano accompaniment of dancing pieces. Heraclio Fernandez Noya (1851-1886) had a remarkable place there. He wrote in 1876 a manual with the suggestive title: Método para aprender a acompañar piezas de baile/ al estilo venezolano/ sin necesidad de ningún otro estudio y á la altura de todas las capacidades (Method to learn accompaniment of dancing pieces with the Venezuelan style, without the need of any study for all the capabilities). So great was his success that a new, improved and wider issue had to be done in $1883 .{ }^{11}$ This shows the large market this repertoire had.

11 For more information, see M. Palacios, 'Heraclio Fernández, Nuevo método para aprender a acompañar piezas de baile', Revista Musical de Venezuela, № 38 (pp.199-341). 


\section{AND NOW, LET'S PLAY, YOUNG LADIES! $!^{12}$}

Undoubtedly society ladies were the piano players par excellence. Learning to play the piano was part of their education - it allowed them to show off in salons. Many of the foreign travelers that visited the country during this period permanently complained about the piano sound humming through the house windows by the ladies playing it every day at any hour (except during the nap time). ${ }^{13}$

The instrument's popularity among women made it a compulsory item in the syllabi of some Escuelas para señoritas alongside reading, writing, religion, urbanism, arithmetic, grammar, geography, astronomy, sacred history, profane history, and natural history. This curriculum would allow women's training as mothers, wives, and housewives, which was their position within society, while learning as their limited capabilities would allow them. They were believed to be inferior to men, even in the anatomical and physiological way. ${ }^{14}$ Women were regarded as sable, unable to reason clearly, totally dependent on the male figure, extremely voluble and of a weak intelligence. By allowing them to learn fine arts, which were intended to be boosted by the modernity project by Guzman Blanco, no violation was committed to their role in society as virtuous mothers and wives, and housekeeper. This was possible as fine arts were closely related the sensitive and emotive character that women were attributed.

Showing artist women that were outstanding in salons, balls and soirees was a way of displaying the civilization, and even of westernization, especially in European countries (...) Protected and encouraged women's activities are compatible with women's traditional labors and with the concepts constructed by the European bourgeoisie, and repeatedly reinforced throughout the century. ${ }^{15}$

So, throughout the 19th century, in the field of fine arts, and especially in music, women's participation was evident. Their participation was important especially as players and creators, being in the private area as in the public one. One of the roles they were allowed to perform freely was teachers - they would teach piano, especially private lessons. Although as the century passed and as women's inclusion in the formal education system and the creation of some institutions for the artistic teaching, some public education positions were taken by them too.

Some women made their name as composers too, and made public their creations in musical albums and in periodicals such as El Zancudo and El Cojo Ilustrado. Sofia Ramachini de Pecchio (1850-1928), Maria Montemayor de Letts (?) and Isabel Pachano de Mauri (?-1911) are among them.

\footnotetext{
A. Nervo, 'El piano' in Cuentos y Crónicas de Amado Nervo, México 1993.

V. Benedittis, Presencia...

14 See E. Pino Iturrieta, Ventaneras y castas, diabólicas y honestas, Caracas 2009, pp. 28-29.

15 P. Silva Beauregard, De médicos, idilios y otras historias. Relatos sentimentales y diagnósticos de fin de siglo (1880-1910), Santafé de Bogota 2000, pp. 98-99. Quoted in E. González, Las escritoras corianas del periodo finisecular (XIX) y su agenda oculta, Caracas 2010, p. 151.
} 


\section{RECORD EDITION}

To conclude this brief overview of music in 19th-century Venezuela, I will talk about the role that periodicals played in the edition and circulation of the musical repertoire.

Music-related newspapers and magazines flourished during the second half of the 19th century. On their pages can be found information on composers, works, players, events, concerts, critical reviews, chronicles, news about a foreign artist's visit to the country, news on the whereabouts of Venezuelans abroad, remarks on the performance of bands, information on music education, remarks on the aesthetics, information on folklore, comments on general music topics published in foreign magazines, etc. The many musical news items in many newspapers show a varied musical activity in many fields.

Some of these publications included, along with valuable information, scores. The edited repertoire met the needs of the music played in salons, dancing genres, and European-style concert pieces, mostly written for the piano. We can also find some singing and piano compositions, and some few violin and piano ones. Notable are recitations or melopeas (melopeyas), a totally outdated genre, made up of poems to be recited with the pianist's playing. It was a sort of accompanied recite where reading and music merged.

Among the musical-related 19th-century publications was the El Zancudo newspaper, a weekly literary and fine arts paper founded and managed by Heraclio Fernandez and Gabriel Jose Aramburu, from Zulia, both editors and owners. The first publication was on January 9th 1876 . The publication was obviously musical critique-oriented, with some kind humor or irony. Of the four pages thereof, the cover was a caricature (generally political), or the portrait of an artist, politician or outstanding person. The second and third pages, printed in two or three columns, contained poems, speeches, thoughts, jokes, the explanation of opera and zarzuela arguments or criticisms on an important person or event. The last page contained the musical work, generally of Venezuelan authorship.

Another magazine that published musical scores was La Lira Venezolana, a biweekly musical and literary publication edited by pianist, composer, and instructor from Cumana - Salvador Narciso Llamozas. The first issue was published on October 28th 1882 , and although its duration was only 1 -year long (until November, 1883), among its collaborators were the best writers of that time, such as Ramon de la Plaza, Domingo Santos Ramos, Eugenio Mendoza y Mendoza, Marco Antonio Saluzzo, and Domingo Ramon Hernandez. There was contained a musical supplement attached to the magazine in the second monthly issue where works of famous Venezuelan musicians such as Llamozas, Francisco Tejera, Manuel Azpurua, Leopoldo Sucre, Jesus Maria Suarez, and Federico Villena, and others appeared.

Among the general magazines containing musical records are El Cojo Ilustrado, described by historian Pedro Grases as the best bi-weekly newspapers Venezuela has ever had. Edited by Jose Maria Herrera Irigoyen, El Cojo Ilustrado reached the outstanding number of issues - 559, and a printing of 660 copies on a bi-week basis, making it wi- 
thout any doubt one of the most important historiography sources by the end of the 19th century and early 20th century. Its first issue was in 1892 and its last one was in 1915. For 22 years and 5 months, El Cojo Ilustrado informed about political, social, financial, cultural and musical events in Venezuela and worldwide. Many of its copies contained compositions by Venezuelan authors, and sporadically some musical supplements were published.

As evinced, the most outstanding male and female composers would try to write music to be published in these newspapers and magazines, due to their massive circulation.

\section{CODA}

This brief overview of the Venezuela music in the mid-19th century was possible because of the periodicals of that time, which are an endless information source. Source collection is a long and still ongoing process. However, the obtained data so far allow an approach to music of an undeniable transcendence refuting the information in Venezuelan bibliographic references, telling of the poor development of the arts due to the country's political instability and narrow circumstances.

Undoubtedly, the knowledge of what happened during that period is useful in order to understand what we are now as a country.

\section{REFERENCES}

Almandoz M.A., 'Postales de viajeros olvidados a la Caracas de entre siglos' in J.J. Martín Frenchilla, Y. Texera (comps.), Asi nos vieron. Cultura, ciencia y tecnología en Venezuela 1830-1940, Caracas 2000, pp. 31-76.

Benedittis V., Presencia de la música en los relatos de viajeros del siglo XIX, Caracas 2002.

Curtis W.E., Venezuela. A land where it's always summer, New York 1896.

El Mercurio Venezolano, № 2, February 1811.

El Zancudo, Año 5, Mes 4, № 10, 25 April 1880.

González E., Las escritoras corianas del periodo finisecular (XIX) y su agenda oculta, Caracas 2010.

Guillén Y., A. Medina, T. Quintero, Noticias musicales en el diario La Opinión Nacional, tesis de grado multimedia, Caracas 2008.

Lisbona M.G., 'Salvador Narciso Llamozas, Lira Venezolana y Nacionalismo musical', Revista Musical de Venezuela, № 41 (2000), pp. 209-226.

Llamozas S.N., 'El valse venezolano', La Lira Venezolana. Revista quincenal de Música y literatura, No 14 (1883), pp. 65-66.

Nervo A., 'El piano' in Cuentos y Crónicas de Amado Nervo, México 1993, pp. 110-111.

Palacios M., 'Heraclio Fernández, Nuevo método para aprender a acompañar piezas de baile', Revista Musical de Venezuela, № 38 (1998), pp. 299-342. 
Pino Iturrieta E., Ventaneras y castas, diabólicas y honestas, Caracas 2009.

Rodríguez Legendre F., Caracas, la vida musical y sus sonidos (1830-1888), Caracas 1999.

Salcedo-Bastardo J.L., Historia Fundamental de Venezuela, Caracas 1993.

Santana Y., R. Campomás, Noticias musicales en el Diario de Avisos, tesis de grado multimedia, Caracas 2005.

Silva Beauregard P., De médicos, idilios y otras historias. Relatos sentimentales y diagnósticos de fin de siglo (1880-1910), Santafé de Bogotá 2000.

Mariantonia PALACIOS, Performer Piano Professor, Escuela de Música Juan Manuel Olivares (1982); Bachelor of Arts, Universidad Central de Venezuela (1984); Maestro Compositor, Juan José Landaeta Conservatory (1987); Magíster Scientiarum in Latin American Musicology, UCV (1998); Magister Artium, University of Costa Rica (2003). Titular Professor at Universidad Central de Venezuela; Vissiting Professor at Universidad Simón Bolívar, Universidad Metropolitana (Caracas), and University of Costa Rica. Curator of the collection Music in Colonial America, and co-curator of the colletion Clásicos de la Literatura Pianistica Venezolana, and Fuentes para el estudio de la música en Venezuela. Former Director of the School of Arts (UCV), the Choir of the Teresa Carreño Theater (Caracas), and the National Opera Company of Costa Rica. Coordinator of the Latin American Musicology Master, the Digital Arts Center, and the Liberal Arts Certified (UCV). National Research Award Rházes Hernández López in Musicology, Caracas, 1998; Honourable Mention in Premio de Musicología Casa de las Américas, Havana, 1999; Honorable Mention Award Samuel Claro Valdés, Chile, 2000; Award José María Vargas for academic merits, Caracas, 2004; Honorable Mention Award CENAL, Caracas, 2005; Municipal Music Award in Musical Research, Caracas, 2009; Honorable Mention Award CENAL, Caracas, 2010. 